logical conditions at Greenwich during the year ending April 30, 1916, are: (i) the warm January with a mean temperature $2^{\circ}$ higher than any January from 1841 to 1915 ; (ii) the great pressures of wind in the gales in the winter; and (iii) the heavy rainfall in March, the wettest March since the commencement of the Greenwich records in $184 \mathrm{I}$.

The following details of the chronicle of the weather refer to the year ended April 30, 1916. The mean temperature was $49^{\circ}$, or $O \cdot I^{\circ}$ above the average of the seventy years $1841-1910$. The highest temperature in the shade was $87.2^{\circ}$ on June 8 , and the temperature exceeded $80^{\circ}$ on only six days, as against twenty-one in the previous year. The lowest temperature was $23.0^{\circ}$ on November 27 , and on forty days fell as low as $32 \cdot 0^{\circ}$.

The mean daily horizontal movement of the air was 287 miles, which is three miles above the average of the previous forty-eight years. The greatest daily movement, 955 miles, was recorded on February 16 ,

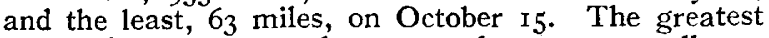
recorded pressure on the square foot was $35.0 \mathrm{lb}$. on January $\mathrm{I}$; the greatest velocity in one hour $5 \mathrm{I}$ miles on December 27 .

The duration of bright sunshine registered by the Campbell-Stokes instrument was 1476 hours, out of a possible 4473 hours, or 33 per cent. This is below the average, principally owing to a deficiency in August and March.

The rainfall was 32.17 in., or 8.05 in. above the average for the period 184 I-I905. The number of rainy days (o.005 in. or over) was I68. June, with 0.56 in., was the driest, and December, with 5.20 in., the wettest month. The rainfall in March was $4 \cdot I_{3}$ in.

The scientific work of the observatory has necessarily been somewhat curtailed, but it has been found possible to keep up all observations of the sun, moon, and planets; sun-spots, latitude; magnetic and meteorological registers; observations which would otherwise be permanently lost. The reductions are in some cases behindhand, and must be brought up to date later. Both the scientific staff and the workmen have made everv effort to cope with the additional work caused by the absence of their normal assistance. In the course of the year six Belgian refugees have been employed at the observatory.

\section{THE PLACE OF SCIENCE IN MODERN METALLURGICAL INDUSTRIES.}

$T^{T}$ is significant of the position which science now 1 occupies in the iron and steel industry that Sir William Beardmore, the head of a great armament firm in Glasgow, and the president-elect of the Iron and Steel Institute, in discussing the various factors which determine the success of any particular process, said in his recent presidential address :- "Science comes first. It is the dominant factor because it should be the beginning of all things. ..." He went on to point out that there is, however, a tendency at the moment to neglect the other factors, and especially the attitude of labour towards improved methods of manufacture which are evolved by scientific research. This attitude amounts in many cases to an absolute refusal to utilise such improvements, and when manufacturers are charged with a lack of enterprise in not adopting modifications which are demonstrably advantageous the reason frequently is that the obstructionist attitude of labour organisations renders those improvements impossible of execution. Sir William Beardmore quite rightly insists that the question is one of profound national importance. He says :-

NO. 2432, VOL. 97$]$
" The employment of the people and their well-being depend upon plenty of work. This in turn requires the maintenance of a great export trade. Efficiency and economy in manufactures can do much to win and retain foreign as well as British Imperial markets. This necessitates advance towards perfection of design and greater volume of output, through improvement in the mechanical means of production evolved by experiment. It follows that research should be a charge upon the selling price. To counterbalance this charge it is essential that the volume of output should be increased. Thus, when we reach the bedrock of industrial conditions we find that unless restrictions and limitations dictated by workers' organisations are abolished much of the gain possible to the nation due to research and experiment must be lost."

Seldom before has this point been made with such brevity and convincingness. Sir William Beardmore went on to give instances of the restrictive methods of trade unions during the war, which would be almost incredible if they were not, as they unfortunately are, amply proved to be true.

One of the best points made in his address was the clear and proper distinction drawn between the two main divisions of scientific research, which he classified as "in one case purely theoretical, almost classical; in the other as distinctly technical, or practical," each of which has its proper sphere. As regards the former, the results obtained merely indicate potentialities for the future; as regards the latter, they are generally contemporaneous with actual manufacture. No more difficult questions come up for decision than the potentialities, from a commercial point of view, of problems which have been solved in the laboratory. It is very encouraging to scientific workers in metallurgy to find such stress laid on the importance of theoretical research by a practical man of the attainments of Sir William Beardmore.

$$
\text { H. C. H. C. }
$$

\section{RECENT ENTOMOLOGY.}

THE Termites, or "white ants," of the United States are described by Thomas E. Snyder from the bionomic and economic point of view in Bulletin 333 of the U.S. Department of Agriculture. Three species of Leucotermes-one an introduced immigrant from South Europe-are included in the survey. The principal injury caused by the termites is the destruction of wooden buildings and other structures, but at times they devour living trees and growing crops, as well as books, papers, cloth fabrics, and stored grain and flour.

From the current number (part 3 , vol. iv. B) of the Review of Applied Entomology it is evident that the destruction of lice infesting troops on the Eastern battlefront is a problem confronting both German and Russian army surgeons and sanitarians. From a summary of Dr. A. Hase's recent paper in the Centralbl. Bakt. Parasit. u. Infektionskrankh (lxxvii., 2, 1915), we learn that dirty, greasy underclothing causes a high temperature which is deterrent to lice, and we are struck by a touch of human interest rarely found in the summary of a technical paper. "The troops were all anxious to be freed from the pests with the exception of an East Prussian, who said that the little creatures reminded him of home."

A recent number (vol. iii., 3) of the Indian Journal of Medical Research contains some papers of interest to students of the Diptera. Major S. R. Christophers revises the list of Indian Anophelini, and describes the various stages of Anopheles plumbeus-a species apparently common to Europe, North America, and India-the larvæ of which were found inhabiting holes 
in tree-trunks near Simla. Baini Prashad describes the microscopical structure of the halteres in mosquitoes, and discusses their use, believing that the equilibrating sense is the only function certainly attributable to the organs, which appear to have no connection with sound production or stridulation. The same author gives an account of the internal male organs in several mosquito genera. A paper of very considerable importance by P. R. Awati, entitled "Studies in Flies, II.," contains descriptions of the genital armature in several Muscid genera as compared with those of other Diptera, illustrated by nineteen clearly drawn plates. The author points out that ten segments may be represented in the abdomen of the higher Diptera, confirming the view put forward by G. H. Carpenter and T. R. Hewitt in their account of the reproductive organs of warble-flies (Hypoderma) published in 1914 (Sci. Proc. R. Dublin Soc., vol. xiv., No. I9). Mr. Awati attempts to co-ordinate the inconveniently divergent terminology which has grown up in connection with the male armature of flies studied by various writers.

The important families of the Tabanidæ and Therevidæ are dealt with in part ii. of A. White's monograph of the Diptera-Brachycera of Tasmania (Proc. R. Soc. Tasmania, I9I5, pp. I-59).

In the Journ. Agric. Research (vol. v., No. 12) D. G. Tower writes on the "Biology of Apanteles militaris," a parasite of the noctuid moth, Heliophila (or Leucania) unipuncta, the caterpillar of which is notorious in North America under the name of "army worm"; he describes the outlines of the embryonic development, the hatching of the larva, and its various stages. The whole life-history occupies about twenty-five days. Parthenogenesis may occur; all the offspring of virgin females appear to be males. The author discusses the function of the curious embryonic outgrowth of the hind-gut, known as the "caudal vesicle," and agrees with the view of $R$. Weissenberg (Sitzb. Gesellsch. naturf. Freunde, Berlin, I9OI, I) that it is a temporary organ of excretion. Prof. Vernon L. Kellogg and Gordon F. Ferris publish, in the Stanford University Series (California), some valuable notes on the Anoplura and Mallophaga of North American mammals. They point out that the systematic study of the Anoplura has been markedly neglected, and furnish a diagnostic table of families and genera which will prove useful to students. The importance of these blood-sucking insects as transmitters, and possibly as alternate hosts, of Protozoa causing disease in mammals is naturally emphasised.

Students of economic entomology and of sacred history will alike be attracted by John D. Whiting's article on a recent plague of locusts near Jerusalem in the National Geographic Journal (Washington, vol. xxviii., No. 6). This article gives a vivid description of the locust swarms and the damage done by them to vegetation; it is illustrated by a most remarkable series of photographs.

G. H. C.

\section{UNIVERSITY AND EDUCATIONAL} INTELLIGENCE.

OXFORD.-A party of sixteen professors from various universities in France has lately visited Oxford. They received a cordial welcome, and were given ample opportunities of observing the effect of the war upon the life of the University.

Prof. A. Schuster has been appointed Halley lecturer for 1917 .

Owing to circumstances connected with the war the election of a reader in geography is postponed until further notice.

NO. 2432 , VOL. 97]
By the will of the late Miss C. E. Beckwith onehalf of the residue of her estate, which amounts to about $8000 l$., is bequeathed to the Victoria University of Manchester in aid of the "John Henry Beckwith Scholarship," founded by her mother.

Science announces that by the will of the late $\mathrm{Mr}$. C. W. Harkness Yale University will receive $100,000 l$. and the Harkness Fund for scientific and educational work 50,00ol. It is also announced that a bequest of 30,00ol. has been made to the Johns Hopkins University by Miss Jessie Gillender for the purpose of instituting organised research into the problem of epilepsy.

Some months ago the German authorities removed to Germany as prisoners two professors of the University of Ghent, Messrs. Frédéricq and Pirenne, against whom no charge was made and no reason was given. The Dutch Government afterwards approached the German Government with the view of obtaining their release; and now a memorial has been sent with the same object to the Berlin Academy of Sciences, to other German academies and learned societies, to the senates of the German universities, and individually to a large number of German professors. There are nearly 200 signatories, all professors in Dutch universities or members of the Academy of Sciences of Amsterdam, and the list includes many of the bestknown names of Dutch science. The memorialists call upon their German colleagues to obtain from the Government permission for Profs. Frédéricq and Pirenne to proceed to Holland, in order to continue their studies there They are convinced that a refusal would seriously disappoint a large part of the Dutch nation.

UNDER the title, "Om Borns Idealer," Dr. A. Lehmann has published (Kgl. Danske Videnskabernes Selskabs Forhandlingen, I916, No. 2, pp. 107) an illuminating analysis of the replies given by 4602 Danish children to the question, "What person would you wish to be like, and why do you prefer the model you have chosen?" The subjects of the inquiry were selected from five distinct types of schools, and included boys and girls of all ages from eight to sixteen. Many interesting points are brought out--for example, that although parents and other personal acquaintances fail badly to maintain their original position as the heroes of childhood, they tend to be rehabilitated in the esteem of the adolescent. Taking the results as a whole, the curves showing the preferences of the two sexes for persons, virtues and accomplishments fall rather widely apart. In a final section of the paper the author seeks to determine the influence of co. education upon the course taken by these curves, and shows that it represents something much more positive than a mere tendency to bring the views of boys and girls closer together.

DURING the past year the sub-committee on research funds of the Committee of One Hundred of the American Association for the Advancement of Science has tried to secure information regarding research funds in the United States, and particularly such as are available without substantial limitations as to the residence and so on of the person receiving the grant. A list of the more important endowments to which no restrictions are attached, with the exception of those devoted to medical research, has been prepared, and is published in the issue of Science for May 12. The total capital value of these endowments is $4,603,150 l$. and those funds where the endowment reaches $5000 l$. or more are as follows:-The Carnegie Institution, 4,400,00ol.; the Smithsonian Institution, 50,000l.; the Engineering Foundation Board, New York City, 